Article

\title{
Changing Paradigms: A Sketch for Sustainable Wellbeing and Ecosocial Policy
}

\section{Tuuli Hirvilammi ${ }^{1, *}$ and Tuula Helne ${ }^{2}$}

1 Department of Social Research, University of Helsinki, Snellmaninkatu 10, PO Box 16, Helsinki 00014, Finland

2 Research Department, The Social Insurance Institution of Finland, Nordenskiöldinkatu 12, PO Box 450, Helsinki 00101, Finland; E-Mail: tuula.helne@kela.fi

* Author to whom correspondence should be addressed; E-Mail: tuuli.hirvilammi@helsinki.fi; Tel.: +358-40-726-2254.

Received: 28 February 2014; in revised form: 2 April 2014 / Accepted: 4 April 2014 /

Published: 15 April 2014

\begin{abstract}
We live in the Anthropocene era, where human action has an unforeseen impact on global ecosystems. This is visible, for instance, in climate change, in the loss of biodiversity and in the acidification of the oceans. Little attention is given to the fact that the Anthropocene is related to anthropocentric thinking that also guides our policies. Therefore, we argue that ecologically and socially sustainable policies will not be achieved by incidental policy measures alone, but a change of paradigm is needed. In our article, we lay out the tenets of a relational paradigm resting on holistic thinking and deep ecology. On the basis of this paradigm, the principles, conceptions and goals specific to any given policy can be formulated, giving them a common ground. In this article, we apply the relational paradigm to social policy in order to contribute to the quest for sustainable wellbeing in the overconsuming welfare states. Here, we formulate a multidimensional and relational conception of wellbeing, the HDLB-model (Having-Doing-Loving-Being), which is a modification of sociologist Erik Allardt's theory. We illustrate how this model could provide the foundation of a sustainable ecosocial policy.
\end{abstract}

Keywords: wellbeing; sustainability; social policy; environment; relationality 


\section{Introduction: On Paradigms and Policies}

"Vision is the most vital step in the policy process." [1]

Ours is the era of the Anthropocene, where human action has unforeseen impacts on global ecosystems. The "human colossus" [2] (p. 510) is increasingly crowding out other species in order to satisfy its gigantic appetite for natural resources. It has led to the current mass extinctions, the overshoot of the carrying capacity of the planet and the worsening scenarios of climate change. Humans have changed ecosystems to an extent to which biological resources are going to endure rapid and unpredictable transformations within the near future (e.g., [3]).

All this will bring about severe difficulties for human wellbeing, since we are highly dependent on the biological resources and climatic environment we often take for granted. We thus face the grave dilemma of how we and the future generations - humans and non-humans alike — shall be able to live good lives without eroding ecosystems. The question is especially critical in the affluent welfare states, where the ecological footprint is almost five times bigger than in poor nations [4]. Therefore, we need policy solutions that promote human wellbeing while simultaneously decreasing human pressure on the biosphere.

The concept of paradigm became widely known through the seminal book The Structure of Scientific Revolutions by Thomas Kuhn (originally 1962) [5]. He wrote about scientific paradigms, but the concept is increasingly used when referring to any mental models predominant in society. When discussing the sustainability transition, surprisingly little attention has been given to the fact that the origins of the Anthropocene are in our anthropocentric mental models. Paradigms can be seen as the driving sources of systems, since they constitute the "deepest set of beliefs about how the world works" [6] (pp. 17-18), [7] (pp. 116-117). The anthropocentric paradigm with its taken-for-granted assumptions also forms the general framework for more specified policy paradigms. It constitutes the "conceptual blinders" that make it difficult for policymakers to recognize the seriousness of the present ecological crisis [8] or make them prone to favor policy solutions that, due to the severity of the ecological crises, are not sufficient. For instance, leaning on the anthropocentric paradigm, environmental policymakers place high hopes on ecological modernization centered on clean technologies. As valuable as these innovations may be, we see them as ad hoc measures that leave the deeper problems uncorrected (see [9], p. 488). How is the sustainability transition possible if the ideas that guide our actions and policies remain untouched?

Sharing the view held by a large number of environmentally-oriented scholars [10-12], we argue that a sustainability transition on the policy level presumes a fundamental shift in conceptual frameworks and our thinking patterns. Changes in the ideas and paradigms can significantly influence the direction of policy practices, as is shown in the institutional approach in political sciences $[13,14]$. Meadows [6] has also emphasized that the most effective leverage point for changing a system is to change its paradigm. If basic assumptions are challenged, new systemic insights into organizing a society can arise. On the basis of changes in the foundational paradigm, the principles, conceptions and goals specific to any given policy could be formulated, giving them a common ground for sustainable practices. In this article, we develop this line of thinking by focusing on social policy and wellbeing. We sketch how social policy, leaning on a relational, ecologically and socially sustainable paradigm, could revise first its conception of wellbeing and then the welfare system itself, the result being an 
integrated and coherent ecosocial policy. Our broad aim is to contribute to the quest for sustainable wellbeing in the overconsuming welfare states.

We will proceed as follows: First we turn our attention to the basic assumptions of the anthropocentric, human exemptionalism paradigm, and elaborate its antithesis, the relational paradigm. Second, we illustrate how the adoption of this paradigm could influence the conception of wellbeing (i.e., the goal of social policy) by broadening and deepening its content. We formulate the relational and multidimensional conception of wellbeing, the HDLB-model (Having-Doing-Loving-Being), which is a modification of sociologist Erik Allardt's theory. Third, we explore how this relational conception of wellbeing could be applied on the policy level, providing some examples of ecosocial policy practices. To conclude, we discuss the feasibility of the paradigm change we have outlined in our article.

\section{The Pitfall of the Human Exemptionalism Paradigm and the Promises of Relationality}

Western welfare states are based on a long history of an anthropocentric tradition, where the development of human societies is seen as nearly independent from ecological constraints [15]. Sociologists Catton and Dunlap [8] (p. 25) have called the fundamental paradigm in social sciences the "human exemptionalism paradigm", due to the often held assumption that "the exceptional characteristics of our species exempt us from ecological principles and from environmental influences". Because of the severe ecological crisis, these kinds of unstated, fundamental assumptions should be brought into daylight. Therefore, further developing the lists and ideas provided by Bateson [9] (pp. 492-493), Catton and Dunlap [8] (pp. 17-18), [16] (pp. 42-43), Milbrath [7] (p. 119) and Meadows [1,6,17], we have formulated the following heuristic list of the basic assumptions, which, we argue, figure in the anthropocentric, human exemptionalism paradigm:

(1) Humans are separate from nature. Unilateral domination of the natural environment is feasible and desirable.

(2) Nature is a stock of resources to be converted to human purposes. Environmental sink and source capacities are infinite.

(3) Humans are superior to other species, which gives mankind the right to exploit them.

(4) High value is placed on the single individual or the single nation; it is me or us against others.

(5) Mainly the benefits gained in the short term are taken into account in our action.

(6) Progress is equated with endless economic growth, and wellbeing is largely associated with the material standard of living.

(7) Risks are accepted and actively embraced.

(8) The problems we face can be solved through technological development.

(9) Economic considerations are paramount in decision-making.

(10)Rational faculties are seen as superior to intuitive and affective faculties.

We claim that these taken-for-granted assumptions constitute the background to the unsustainable policies in the Western welfare states. The human exemptionalism paradigm influences social policy in many ways. For instance, as human progress has been equated with material growth, the concept of wellbeing has been largely understood in terms of monetary or social resources and seen as identical 
with prosperity [11]. Social policies in Western welfare states have had the inbuilt objective of protecting people against social risks and to raise their standard of living, which has been valuable for combating poverty and increasing common wellbeing. Yet, these goals have been put into practice at the expense of future generations, largely due to the fact that welfare states have been closely linked to the aim of economic growth [18].

Originally, the anthropocentric ideas and the ideology of domination over nature lay at the center of the attempts "to transform the world into a more loveable, friendlier, lighter and safer place" [15] (p. 7). However, the consequences of implementing these ideas have turned out to be something of a Pandora's box, because in the last resort "( $\mathrm{t}$ )he creature that wins against its environment destroys itself" [9] (p. 493). To that end, the ecosocial risks that imperil human wellbeing in the future are also in stark contrast to the promises of security and wellbeing made in the welfare states.

The social and ecological dilemmas we face challenge the prevailing anthropocentric paradigm. From a Kuhnian perspective, these dilemmas could, paradoxically, enhance the sustainability transition, because a paradigm ultimately changes in response to the accumulation of anomalies and phenomena it cannot explain [5]. At the policy level, old paradigms give way to new ones if policy makers face problems for which the current paradigm provides no clear-cut solutions [14]. Peter A. Hall [13] relates a paradigm shift to a social learning process, where policy goals and measures alter due to past experiences and new information. Better knowledge and new experiences on the ecosocial crisis have already given rise to more ecocentric ideas. In fact, a "new environmental paradigm" is emerging, as Lester W. Milbrath [7] discovered and claimed already a quarter-century ago.

Although the anthropocentric tradition is still dominant, many environmental and social scientists have already adopted an ecocentric and relational worldview building on the interdependence of all life forms on Earth (see [19]). This relational view of existence is central to the deep ecology or ecosophy developed by Arne Naess starting in the 1970s. He sees the individual as inseparably embedded in a complex, intricate web of relationships. In his "everything hangs together' maxim of ecology" [20] (p. 230), the parts of systems are understood as working together. From this perspective, ecosystems not only offer services in support of human wellbeing, but are its very precondition. In other words, the human relationship with nature is no longer parasitic, but symbiotic [21].

In relational thinking, deep attachment to the living nature around us is possible only if we see ourselves as equal with other living things and do not try to dominate the natural environment. When humans are at one with all that exists, they are the ecosystems themselves. This being so, they are more likely to be non-violent and to protect the non-human ecosystems, as if they were protecting and caring for themselves. To describe this relationship, Naess [20] has introduced the concept of the "ecological self". In it, our self is widened and deepened and no longer confused with the narrow ego. This is a radical change in our self-conception. In the words of Kenneth Gergen, the presumption of bounded selves is replaced with a vision of relationship. This does not refer to a relationship between separate selves, but rather, a process of coordination that precedes the very concept of the self [22] (p. xv).

Following this line of argument and inspired once more by Bateson [9] (pp. 492-493), Catton and Dunlap [8] (pp. 17-18), [16] (pp. 42-43), Milbrath [7] (p. 119) and Meadows [1,6,17], we have formulated a heuristic list, the antithesis of the previous one, that expresses some of the assumptions of the relational paradigm: 
(1) Humans are a part of nature; we are fundamentally interconnected with ecosystems.

(2) Nature is an ally that provides us with all we need for living. The boundaries and regenerative capacities of ecosystems are respected.

(3) All species are interdependent, and all living creatures are intrinsically valuable.

(4) High value is placed on the web of relations, and our horizons for caring are wide.

(5) Human activities have both immediate effects and effects that radiate for centuries to come.

(6) Progress means sustaining healthy living conditions for all species on Earth. Wellbeing is understood relationally, and nonmaterial aspects of life are appreciated.

(7) Precaution and risk avoidance are important guidelines for our action.

(8) Technology offers useful innovations for sustainable needs satisfaction.

(9) Decision-making is based on holistic deliberation. Environmental protection and social sustainability outweigh economic aspects.

(10)Humans rely not only on their intelligence, but on their intuition, emotions and inner wisdom.

The list is formulated in positive terms, because not everybody envisions a sustainable world as one that would be uncontestedly wonderful to live in; instead, there is talk about restrictions, prohibitions, regulations and sacrifice [1]. There may be some truth here, but we believe it to be more recommendable to pay attention to what will be gained by the sustainability transition. Next, we will turn our attention to the relational conception of wellbeing.

\section{Relational Understanding of Wellbeing}

Human wellbeing is the ultimate goal of social policy. However, in the present welfare states, policy makers have not felt the need to discuss and define it. Instead, at the hub have been the instruments and indicators of wellbeing. Focusing on material wealth, these indicators tend to neglect the new wellbeing problems, such as stress and a hurried way of life, depression, loneliness, substance abuse and environmentally destructive behavior [23].

In this article, we argue that without a more profound interest in the content of wellbeing, the possibility of a sustainability transition in welfare states is unlikely. We have to get back to the basics and ground the policies in clearly formulated ultimate ends: a more holistic understanding of human needs and wellbeing is therefore in order. A broader understanding of wellbeing will then be the "hard core" around which sustainable societies can be built [23] (p. 13).

Going to the core, then: what is wellbeing, and how could it be approached in the context of the relational paradigm? The quintessential question of what wellbeing is has been debated for thousands of years, and no settled consensus has yet been achieved [24]. To make things quite simple, we start from the assumption that wellbeing is something that all species recognize and wish to experience in their lives and surroundings [25]. For humans, wellbeing is the highest value, intrinsic to human nature [26]. To describe the indescribable, we borrow the words of Erich Fromm [27] (p. 91): "Well-being means to be fully related to man and nature affectively, to overcome separateness and alienation, to arrive at the experience of oneness with all that exists". This does not mean that wellbeing is a permanent state of subjective satisfaction or objective circumstances that could be achieved once and for all [24]. Instead, we see wellbeing as an aspiration and a process of self-actualization that could more aptly be called well-becoming. 
This conception is in line with the idea of self-realization introduced by Naess. He argues that "[t]he meaning of life, and the joy we experience in living, is enhanced through increased self-realization, that is, through the fulfillment of potentials that each of us has" [20] (p. 226). In line with eudaimonic approaches to wellbeing, he does not conceive of human wellbeing in terms of pleasure or happiness. Instead, his idea of the ultimate goal of life lies in the inherent realization of the potentials of all living beings. The same idea can be seen in the theory of human needs and human motivation of Abraham Maslow (original 1962) [26] (p. 118), in which the highest jewel in the crown of needs satisfaction is self-actualization or "full-humanness". Contrary to some misunderstandings, these concepts do not focus on individual gains. Instead, Maslow highlights altruism, dedication, the ties to other people and society, egolessness and self-transcendence. Hence, the main function of a healthy culture is the fostering of self-actualization [26,28]. Interestingly, a similar idea of interwoven individual and social progress can be seen in the aim of flourishing put forward by today's degrowth discussion [29].

Important in the Maslowian conception is the emphasis on the positive potential of human beings, a perspective that is often neglected in the needs-based wellbeing research. It has mostly paid attention to what people lack (deprivation) rather than how they could fulfill their potentials and capacities. In addition, Maslow makes a helpful distinction between deficit or deficiency needs and growth needs. The difference is that the latter are rather whetted than allayed by gratification. In other words, their growth is in itself a rewarding and an exciting process [26] (this may be the one and only thing in which endless growth is possible and desirable). Along with Maslow and other theorists of needs [30], we argue that wellbeing depends on the possibilities people have to adequately actualize their fundamental needs of both kinds.

People actualize their needs with the help of different goods, different ways of acting or different institutional structures. A distinction between needs and their satisfiers can thus be made [31]. For instance, food and shelter are not needs as such, but satisfiers (i.e., the means to satisfy needs). It can be argued that fundamental human needs are universal, whereas satisfiers change over time and vary across cultures [30,32]. The distinction between needs and satisfiers is akin to the differentiation between ends and means. The primary goal of a sustainable society would be to produce the greatest possible need satisfactions ("ends") with the least, or wisest, possible satisfiers ("means") [24,32].

\subsection{The Dimensions of Relational Wellbeing}

Wellbeing is multidimensional. Human needs constitute a system in which needs are interrelated and interactive [30]. The multidimensional conceptualization of wellbeing corresponds to the relational paradigm, since it concentrates on the holistic nature of wellbeing rather than its singular aspects. The idea of multidimensionality also includes interdependence, for the different dimensions are not seen as separate components of human wellbeing, but as related to each other: wellbeing is possible only when needs are more or less satisfied on all dimensions. This interdependence also means that one dimension cannot easily be substituted for another.

For heuristic reasons, the dimensions of human wellbeing can be divided into categories summing up the existential core of different needs. Sociologist Erik Allardt has developed an illustrative conceptualization of wellbeing in which he defines "the central necessary conditions of human 
development and existence" in three words: Having, Loving and Being [33]. There is a rough correspondence between this tripartite classification and Abraham Maslow's need theory [34].

Echoing the ecocentric and relational paradigm, Allardt [35] also argues for a new, broader content for wellbeing that could be achieved by taking environmental concerns into account and studying the relationships between the quality of the social and the biological environment. An understanding of relationality can also be sensed in Allardt's [34] (p. 12) statement that "there is a greater emphasis on love as giving than as receiving". Thus, human wellbeing is not about hoarding possessions for oneself, but more about contributing to the common good.

In what follows, we will apply Allardt's theory as a basis of our multidimensional model of wellbeing; developing it further by adding a fourth dimension; Doing. For Allardt, Doing was a part of Being. His indicators of Being measure, for instance, the extent of participation in decisions, political activities and opportunities for a meaningful work life or for leisure-time activities (Doing) [36]. However, we find a clear distinction between Doing and Being useful, because, on the one hand, it emphasizes human activities as a source of wellbeing and, on the other hand, points to the central role of harmony, integrity and presence in human wellbeing. In short, we call our model the HDLB-model. In it, the dimensions are interrelated. The relational paradigm functions as our bedrock for defining the content of the different dimensions.

\subsubsection{Having: Decent and Fair Standard of Living}

The dimension of Having refers to the satisfaction of needs that have to be fulfilled through material and impersonal resources, including natural resources [37]. It covers the necessary material conditions for survival and "needs for nutrition, air, water, for protection against climate" [35] (pp. 3-4). These needs are typically deficit needs that tend to increase the demand of resources. However, when society is aiming at sustainability, the demand should not exceed a morally and ecologically defined optimal level of need fulfillment [32]. The dimension of Having has to incorporate the awareness of the limits of the carrying capacity of the planet (or of one's body) and a corresponding commitment to restricting the use of natural resources.

The needs of Having are met through material resources, such as:

- Natural resources: water, food, materials for clothing, construction, etc.

- Economic resources: income and wealth

- Shelter

- Energy

- Basic consumption items

\subsubsection{Doing: Meaningful and Responsible Activities}

Wellbeing depends on the quality of our actions. Different activities can either enhance wellbeing or diminish it, both on an individual and on a system level. Moreover, the dimension of Doing highlights the fact that humans are inherently active beings who strive to fulfill their needs and are able to reflect and change their actions. Studies show that intentional activity influences a person's happiness more than circumstances and almost as much as her genetic set point. This means that 
changing one's activities probably provides a greater happiness boosting potential (or wellbeing in general) than changing one's circumstances [38]. Furthermore, Doing has its ecological consequences: the everyday activities a person is engaged in differ in their environmental impacts [39].

The needs of Doing can be actualized by many different kinds of activities a person is engaged in, such as:

- Meaningful paid work

- Social and political action

- Housekeeping

- Education and learning

- Leisure-time activities

- Nature activities (gardening, hiking, etc.)

\subsubsection{Loving: Connective and Compassionate Relations to Others}

Human wellbeing depends on the quality of the interaction with the social and natural world around us. On the dimension of Loving, the focus is on the need to relate to others, form social identities and on the need of caring and being socially anchored in communities [34]. Loving also relates to interaction with other species and the natural environment. The field of ecopsychology has shown that relations with nature have a vital importance for human wellbeing (e.g., [40]). The state of the natural environment influences the Loving dimension of wellbeing in many ways. For example, Allardt [36] assumes that if the physical environment deteriorates, people will have less capacities for solidarity and love.

The needs of Loving can be fulfilled by belonging to or caring for:

- Family and kin

- Friends

- Local communities and society

- Global community and future generations

- Other species and nature

\subsubsection{Being: Alert Presence}

For Allardt [41] (p. 7), the dimension of Being implies "the needs of integration into society and for living in harmony with nature". One could extend this idea by stating that Being involves alert presence and harmony. Ultimately, Being refers to the need of self-actualization and personal growth [34]. As a matter of fact, then, Being is quite close to becoming: "the human being is simultaneously that which he is and that which he yearns to be" [26] (p. 123). Physical and mental health can also be included in the dimension of Being, because those persons whose (mental) health is relatively good have the best preconditions for self-actualization. In other words, the cognition of Being "is found more often in healthy people and may even turn out to be one of the defining characteristics of health" [26] (p. 139).

The needs of Being can be fulfilled, for example, when a person

- Is in good physical and mental health; 
- Can fulfill his/her inherent potentials;

- Feels a sense of autonomy;

- Is creative;

- Is striving toward serenity, goodness and unselfishness;

- Has experiences of wholeness, aliveness and self-sufficiency.

Understanding wellbeing in its relational, multidimensional sense and positioning it as the primary goal of social policy might be a vital step in distancing social policy from its association with the ecologically unsustainable paradigm. It would liberate our imagination from present institutions and path dependencies and open up new ways for an integrated ecosocial policy. Let us now turn our attention to rethinking the practices of social policy on the basis of the relational paradigm and the relational idea of wellbeing.

\section{Ecosocial Policy Practices for Promoting Relational Wellbeing}

In order to enhance the sustainability transition, welfare states need to be rebuilt by substituting the ecologically destructive structures with policy measures and institutions that are compatible with the tenets of the relational paradigm. In this chapter, we discuss in brief how to put the paradigm change into practice by describing some possible ways to promote relational wellbeing. We draw on the range of policy ideas and practices that have been presented in the literature on green social policies and in the degrowth or no-growth approaches (see [42]).

A sustainable welfare state requires regulative institutions that place relational wellbeing at its core. The construction of a sustainable welfare state involves legislative changes and comprehensive reorganization of policy measures. First, a longer time span in decision-making is needed in order to safeguard healthy ecosystems and the interests of future generations [18]. Second, given a finite planet, a socially just redistribution of resources is needed. When wholeness is considered more important than individual benefits, it seems more natural to make the claim that rich people should reduce their environmental impact and that poor people should be given more resources for making ends meet [43]. Third, if welfare institutions respect planetary boundaries and accept the limits of technological development, the aim of economic growth will inevitably be called into question. Economic degrowth in affluent welfare states is one often presented solution to achieve a sufficiently rapid rate of reduction of the environmental impacts and to share global resources more equally [29,43]. Contrary to socially unjust economic contraction, a sustainable degrowth means "an equitable downscaling of production and consumption that increases human well-being and enhances ecological conditions at the local and global level, in the short and long term" [43] (p. 512). When this starting point is accepted, there is a need to develop policy practices that can promote wellbeing and ecological sustainability independently of economic growth.

Here, we approach sustainable ecosocial policy practices by asking how to improve wellbeing in all its dimensions. The overview of policy measures is provided in Table 1.

The dimension of Having stands for a decent and fair standard of living. It could be actualized by policies that ensure the essential material preconditions of life for all members of society. The idea of a universal basic income is often promoted as a socially and ecologically sustainable policy practice. A basic income would provide financial security in the flexible and insecure labor markets, 
acknowledge the basic right of each individual to a fair share of common natural resources and ease the positional competition that is a strong driving force for present consumerism. [44,45] Gough and Meadowcroft [46] (p. 498) have also introduced the notion of "a carbon form of the Basic Income idea". It would be based on personal carbon allowances and a trading scheme that would entail a cap on a country's total greenhouse gas emission for each adult resident.

Table 1. The HDLB-model (Having-Doing-Loving-Being) and its policy applications.

\begin{tabular}{|c|c|c|}
\hline Dimension & Indicators & Social policy measures \\
\hline $\begin{array}{l}\text { Having } \\
\text {-a decent and fair } \\
\text { standard of living }\end{array}$ & $\begin{array}{l}\text {-Natural resources: water, food, } \\
\text { materials for clothing, } \\
\text { construction, etc. } \\
\text {-Economic resources: income and } \\
\text { wealth } \\
\text {-Shelter } \\
\text {-Energy } \\
\text {-Basic consumption items }\end{array}$ & $\begin{array}{l}\text {-Basic income } \\
\text {-Idea of a maximum level of income } \\
\text {-Progressive taxation of income and wealth } \\
\text { to cut the overuse of natural resources } \\
\text {-Revenues and progressive environmental } \\
\text { taxes to minimize negative side-effects } \\
\text { for poor households }\end{array}$ \\
\hline $\begin{array}{l}\text { Doing } \\
\text {-purposeful and } \\
\text { responsible activities }\end{array}$ & $\begin{array}{l}\text {-Meaningful paid work } \\
\text {-Social and political activities } \\
\text {-Housekeeping } \\
\text {-Education and learning } \\
\text {-Leisure-time activities } \\
\text {-Nature activities (gardening, } \\
\text { hiking, etc.) }\end{array}$ & $\begin{array}{l}\text {-Increase in the share of socially and } \\
\text { environmentally valuable employment } \\
\text {-Work time reduction } \\
\text {-Fewer opportunities for consumption }\end{array}$ \\
\hline $\begin{array}{l}\text { Loving } \\
\text {-connective and } \\
\text { compassionate relations } \\
\text { to others }\end{array}$ & $\begin{array}{l}\text {-Family and kin } \\
\text {-Friends } \\
\text {-Local communities and society } \\
\text {-Global community and the future } \\
\text { generations } \\
\text {-Other species and nature }\end{array}$ & $\begin{array}{l}\text {-Facilitating caring ethos and practices } \\
\text {-Social benefits and services to support } \\
\text { families and local communities } \\
\text {-Ecosocial social work and green care to } \\
\text { support the human-nature relationship }\end{array}$ \\
\hline $\begin{array}{l}\text { Being } \\
\text {-alert presence }\end{array}$ & $\begin{array}{l}\text {-Good physical and mental health } \\
\text {-Fulfillment of inherent potentials } \\
\text {-Sense of autonomy } \\
\text {-Creativeness } \\
\text {-A strive for serenity, goodness } \\
\text { and unselfishness } \\
\text {-Experiences of wholeness, } \\
\text { aliveness and self-sufficiency }\end{array}$ & $\begin{array}{l}\text {-Favoring slow life and downshifting } \\
\text {-Simplified legislation and comprehensible } \\
\text { implementation of welfare systems }\end{array}$ \\
\hline
\end{tabular}

In addition to a minimum income, policy measures that pay more attention to the overuse of natural resources are also called for [47]. For instance, Herman Daly [48] (p. 202) advocates the idea of maximum income due to the limits of total production growth and to the urgency of a more equal distribution of resources. More redistributive policies would probably limit environmental impacts, because studies show that harmful environmental impacts rise along with income level [49]. The ecologically unsustainable overconsumption of the rich can be reduced by a steeper income tax progression. Consumption-based environmental taxes are also necessary for the sustainability 
transition. However, they tend to hit poorer households harder, and therefore, the regressive effects need to be reduced by paying social benefits or lump-sum revenues [50] or by implementing progressive environmental taxes for energy use. In general, regulatory ecosocial policies focus on the distribution of both economic and natural resources and aim at influencing consumer behavior in order to decrease the environmental impacts of unsustainable living standards, especially those of housing, food and transport [46].

For enhancing wellbeing in the dimension of Doing, the policy practices need to enable human activities that regenerate the social and natural environment. So far, we have come to witness that the activities based on the human exemptionalism paradigm have also consequences that diminish wellbeing. If the relational paradigm were adopted, human activities would be geared towards attaining social and environmental responsibility. This involves, for instance, politicians and civil servants developing greater awareness of both harmful and desirable social and environmental impacts of employment. In employment policies, preference could be given to work with sustainable and positive impacts and a higher social return on investment, such as work done in recycling or by nursery workers or hospital cleaners [51].

Instead of the present emphasis on paid work and activities justified by economic rationalities, the ecosocial policy practices would devote more time to different purposeful and responsible activities. A work-time reduction for full-time employees is often held to be necessary if production is to be cut for ecological reasons [29,52]. Cutting the time spent in paid work would break the work and spend cycle, distribute work more evenly and reduce the ill-being of the unemployed [46]. Reducing working hours might allow more time for active citizenship and leave room for caring responsibilities [53].

This leads us to the dimension of Loving. Building sustainable, connective and compassionate relations requires care and caring communities. Care as an ethical orientation and as a practice is related to greater environmental awareness and responsibility. Therefore, ecosocial policy practices value unpaid care given in families. Activities that collectivize care in communities, such as time banks and other neighborhood initiatives, are also favored [54]. Social benefits for parenting and caring, as well as public social services are given priority to support families and communities.

The dimension of Loving involves caring about the environment, non-human animals and future generations. This caring, and the human-nature relationship in general, could be actively fortified by using the methods of ecosocial social work [55], as well as by means of the increasingly popular green care services [56]. In addition, the existing social services could be decarbonized by developing green alternatives for service delivery [46].

How can policy practices enhance the dimension of Being? It is customary to argue that institutions and policy measures cannot influence individuals' inner experiences of wellbeing. However, the ecosocial policy practices can develop a Being-friendly infrastructure by favoring downshifting, in practice, through the introduction of work time reduction and a basic income, for example. In order to increase the individuals' sense of coherence, and, more generally, the comprehensibility and meaningfulness of life, a simplified and slower life is often called for (e.g., [57]). It can be encouraged by improving sustainable urban planning or health promotion, for example.

There is also a growing "complexity gap" [23] (p. 7) between the mental demands of today's society and the mental capacities of individuals. One complexity gap can be found in the social security system and legislation itself. Therefore, simplifying this system, strengthening transparency, 
cutting down bureaucracy and making it more client-friendly are important parts of Being-friendly social policies.

\section{Discussion and Conclusions: On the Feasibility of Paradigm and Policy Shift}

In this article, we have attempted to lay out cornerstones for an integrated and coherent ecosocial policy by describing first the relational paradigm and its assumptions. Our claim is that the relational paradigm gives a common ground for policy-making in different policy sectors, which would then enable policy integration towards wellbeing within the ecological limits. Second, we argue that the principles and ideas of a new paradigm need to be applied to policy goals, a task we have boldly taken on ourselves in this article, hoping that the HDLB-model of wellbeing could prove to be a useful heuristic tool in the sustainability transition. Third, on the level of policy practices, we illustrate how an understanding of the model could influence the aims and means of ecosocial policy practices. Obviously, the ideas presented here require further development. However, our main focus was on discussing the feasibility of changing paradigms, goals and policies and developing a multidimensional model of wellbeing, not the reconstruction of the welfare system in its entirety.

We are well aware of the enormousness of the task we have presented. To quote Donella Meadows [17] (p. 7), "challenging a paradigm is not part-time work". The anomalies of the present human exemptionalism paradigm have to be exposed over and over again, because there is a social determination not to see them [14,17]. For the sake of clarity, we have presented the sustainability transition proceeding in a linear fashion. It does not mean, however, that we rule out the possibility of the transition starting from new practices or from new habits. As pragmatist reading suggests, the transition and changes in actions are not a linear process, but a process of a continuously evolving cycle of perception, thought and action [58].

Utopian and idealistic as the idea of the wholesale swapping of paradigms may seem to many, we believe in the necessity of taking the plunge. Signs of this happening can be seen in many spheres of life, including academic communities, public institutions and different social experiments. In academic communities, for instance, growing numbers of research fields are integrating ecological concerns into their research programs. Examples include the wide literature on environmental questions and welfare states, the vivid discussion about ecosocial work and the discussion about alternatives to mainstream economics. The call for relational thinking and integrative policies can also be found in policy reports at both the national and international level. In summary, there is still hope of a change of heart, and of wiser action.

\section{Acknowledgments}

The first author is grateful for Finnish Cultural Foundation for providing the funding.

\section{Author Contributions}

The first author was responsible in leading the process and writing early drafts. Both authors were responsible in planning the content of the article and finalising the manuscript. 


\section{Conflicts of Interest}

The authors declare no conflict of interest.

\section{References and Notes}

1. Meadows, D. Envisioning a Sustainable World. Donella Meadows Institute. Available online: http://www.donellameadows.org/archives/envisioning-a-sustainable-world/ (accessed on 3 May 2013)

2. Catton, W. Understanding Humanity's Damaged Future. Sociol. Inq. 2009, 79, 509-522.

3. Barnosky, A.D.; Hadly, E.A.; Bascompte, J.; Berlow, E.L.; Brown, J.H.; Fortelius, M.; Getz, W.M.; Harte, J.; Hastings, A.; Marquet, P.A; et al. Approaching a state shift in Earth's biosphere. Nature 2012, 486, 52-58.

4. Living Planet Report 2012. Biodiversity, biocapacity and better choices. Available online: http://awsassets.panda.org/downloads/1_lpr_2012_online_full_size_single_pages_final_120516.pdf (accessed on 29 May 2013)

5. Kuhn, T. The Structure of Scientific Revolutions, 3rd ed.; University of Chicago Press: Chicago, IL, USA, 1970; p. 210.

6. Meadows, D. Leverage Points: Places to Intervene in a System. Donella Meadows Institute. Available online: http://www.donellameadows.org/archives/leverage-points-places-to-intervenein-a-system/ (accessed on 2 May 2013).

7. Milbrath, L.W. Envisioning a Sustainable Society. Learning Our Way Out; State University of New York Press: Albany, NY, USA, 1989.

8. Catton, W.; Dunlap, R. A New Ecological Paradigm for Post-Exuberant Sociology. Am. Behav. Sci. 1980, 24, 15-47.

9. Bateson, G. Steps to an Ecology of Mind; Ballantine Books: New York, NY, USA, 1985.

10. Bandarage, A. Sustainability and Well-Being. The Middle Path to Environment, Society, and the Economy; Palgrave Macmillan: New York, NY, USA, 2013.

11. Barkin, D.; Lemus, B. Understanding Progress: A Heterodox Approach. Sustainability 2013, 5, 417-431.

12. Assadourian, E. The Rise and Fall of Consumer Cultures. In State of the World 2010. Transforming Cultures; Starke, L., Mastly, L., Eds.; Worldwatch Institute: Washington, DC, USA, 2010; pp. 3-20.

13. Hall, P. Policy paradigms, social learning, and the state. The case of economic policymaking in Britain. Comp. Polit. 1993, 25, 275-296.

14. Campbell, J.L. Ideas, Politics, and Public Policy. Annu. Rev. Sociol. 2002, 28, 21-38.

15. Pattberg, P. Conquest, Domination and Control: Europe's Mastery of Nature in Historic Perspective. J. Polit. Ecol. 2007, 14, 1-9. See: [59].

16. Catton, W.; Dunlap, R. Environmental Sociology: A New Paradigm. Am. Sociol. 1978, 13, 41-49.

17. Meadows, D. System Dynamics Meets the Press. In The Global Citizen; Island Press: Washington, WA, USA, 1991; pp. 1-12. Available online: http://clexchange.org/ftp/documents/ Roadmaps/RM1/D-4143-1.pdf (accessed on 3 May 2013). 
18. Fitzpatrick, T. Challenges for social policy. In Understanding the Environment and Social Policy; Fitzpatrick, T., Ed.; Policy Press and Social Policy Association: Bristol, UK, 2011; pp. 61-90.

19. Besthorn, F. Deep Ecology's contributions to social work: A ten-year retrospective. Int. J. Soc. Welf. 2012, 21, 248-259.

20. Naess, A. Self-Realization. An ecological approach to being in the world. In Deep Ecology for the Twenty-First Century; Sessions, G., Ed.; Shambhala: Boston/London, USA/UK, 1995; pp. 225-245.

21. Serres, M. Le Contrat Naturel; Francois Bourin: Paris, France, 1990; p. 191. (In French)

22. Gergen, K. Relational Being. Beyond Self and Community; Oxford University Press: New York, NY, USA, 2009; p. 418.

23. Hämäläinen, T. Towards a Sustainable Well-Being Society. Building Blocks for a New Socioeconomic Model; SITRA: Helsinki, Finland, 2013. Available online: http://www.sitra.fi/ julkaisut/muut/Towards_a_Sustainable_Wellbeing_Society.pdf (accessed on 10 May 2013).

24. Gough, I.; McGregor, J.A.; Camfield, L. Theorising wellbeing in international development. In Wellbeing in Developing Countries. From Theory to Research; Gough, I., McGregor, J.A., Eds.; Cambridge University Press: New York, NY, USA, 2007; pp. 1-43.

25. This deep intuition can be detected in the responses of the inhabitants of various U.S. communities when they were asked to define indicators of their long-term welfare. They referenced such things as whether wild salmon still run in the rivers, and whether, when opening the window, one can smell the sage. See: [60].

26. Maslow, A. Toward a Psychology of Being, 1st ed.; Wilder Publications: Blacksburg, VA, USA, $2011 ;$ p. 179.

27. Fromm, E. Zen Buddhism and Psychoanalysis, 1st ed.; George Allen \& Unwin: London, UK, 1960; p. 180.

28. This resembles the ideas of capability approach where the aim of human development is an ultimate freedom to exercise human agency and where wellbeing is evaluated in terms of potential freedoms, i.e., capabilities. See: [61].

29. Jackson, T. Prosperity without Growth. Economics for a Finite Planet; Earthscan: London, UK, 2009; p. 264.

30. Max-Neef, M.; Elizalde, A.; Hopenhayn, M. Development and Human Needs. In Human Scale Development: Conception, Application and Further Reflections; Max-Neef, M., Elizalde, A., Hopenhayn, M., Eds.; The Apex Press: New York/London, USA/UK, 1991; p. 114.

31. In the last resort the word "satisfier" is not really compatible with growth needs. When it comes down to deficit needs, the world is organized into gratifiers and frustrators of our needs. As far as the needs of growing are concerned, we see objects in their own right and in their own Being, without reference to their need-gratifying qualities. See: [26] (p. 151).

32. Doyal, L.; Gough, I. A Theory of Human Need; Macmillan: Basingstoke, Hampshire and London, UK, 1991; p. 365.

33. Allardt developed this conceptualization when conducting the Comparative Scandinavian Welfare Study during the first half of the 1970's. See: [62].

34. Allardt, E.; Uusitalo, H. Dimensions of Welfare in a Comparative Study with the Scandinavian Societies. Scand. Polit. Stud. 1972, 7, 9-26. See: [63]. 
35. Allardt, E. Human welfare and non-waste technology. In Technology and Environment. Facing the Future; Johansson, A., Ed.; Finnish Academies of Technology: Helsinki, Finland, 1990; pp. 9-22.

36. Allardt, E. Having, Loving, Being: An Alternative to the Swedish Model of Welfare Research. In The Quality of Life; Nussbaum, M., Sen, A., Eds.; Clarendon Press: Oxford, UK, 1993; pp. 88-94.

37. Originally Allardt did not consider environmental factors here. However, when operationalizing the dimension further he emphasized that to describe the level of human welfare, cumulative environmental problems necessitate measures of the biological and physical environment, such as soil, lake or groundwater acidification. See: [35,36].

38. Lyubomirsky, S.; Sheldon, K.M.; Schkade, D. Pursuing happiness. The architecture of sustainable change. Rev. Gen. Psychol. 2005, 9, 111-131.

39. Hirvilammi, T.; Lettenmeir, M.; Laakso, S.; Lähteenoja, S. Studying well-being and its environmental impacts: A case study of minimum income receivers in Finland. J. Hum. Dev. Capabil. 2012, 14, 134-154.

40. De Vries, S.; Verheij, R.; Groenewegen, P.; Spreeuwenberg, P. Natural environments-Healthy environments? An explaratory analysis between greenspace and health. Environ. Plann. 2003, 35, 1717-1731.

41. Allardt, E. An Updated Indicator System: Having, Loving, Being; Working Papers 48; Department of Sociology, University of Helsinki: Helsinki, Finland, 1989.

42. Koch, M. Welfare after Growth. Theoretical Discussion and Policy Implications. Int. J. Soc. Qual. 2013, 3, 4-20.

43. Schneider, F.; Kallis, G.; Martinéz-Alier, J. Crisis or opportunity? Economic degrowth for social equity and ecological sustainability. Introduction to this special issue. J. Clean. Prod. 2010, 18, 511-518.

44. Andersson, J.O. Degrowth with basic income-The radical combination. Documentation of the 14th BIEN Congress, Munich, Germany, 15 September 2012. Available online: http://www.bien2012.de/sites/default/files/paper_237_en.pdf (accessed on 28 January 2014)

45. Fitzpatrick, T. With No Strings Attached? Basic Income and the Greening of Security. In Environment and Welfare. Towards a Green Social Policy; Fitzpatrick, T., Cahill, M., Eds.; Palgrave Macmillan: Hampshire, UK, 2002; pp. 138-154.

46. Gough, I.; Meadowcroft, J. Decarbonizing the welfare state. In Oxford Handbook of Climate Change and Society; Dryzek, J.S., Norgaard, R.B., Shlossberg, D., Eds.; Oxford University Press: Oxford, UK, 2011; pp. 490-503.

47. Ulvila, M.; Pasanen, J. Transformation scenarios to sustainable economy and equality. In Sustainable Futures. Replacing Growth Imperative and Hierarchies with Sustainable Ways; Ulvila, M., Pasanen, J., Eds.; Ministry of Foreign Affairs of Finland: Helsinki, Finland, 2009; pp. 14-85.

48. Daly, H.E. Beyond Growth. The Economics of Sustainable Development; Beacon Press: Boston, MA, USA, 1996; p. 253.

49. Klugman, J.; Rodriquez, F.; Beejadhur, S.; Bhattacharjee, S.; Chatterjee, M.; Choi, H.J.; Fuchs, A.; Heger, M.P.; Kehayova, V.; Pineda, J.; et al. Human Development Report 2011. Sustainability and Equity: A Better Future for All; Published for the United Nations Development Programme (UNDP); Palgrave MacMillan: New York, NY, USA, 2011. Available online: 
http://www.us.undp.org/content/dam/undp/library/corporate/HDR/2011\%20Global\%20HDR/ English/HDR_2011_EN_Complete.pdf (accessed on 10 May 2013).

50. Büchs, M.; Bardsley, N.; Duwe, S. Who bears the brunt? Distributional effects of climate change mitigation policies. Crit. Soc. Pol. 2011, 31, 285-307.

51. Lawlor, E.; Kersley, H.; Steed, S. A Bit Rich. Calculating the Real Value to Society of Different Professions; New Economics Foundation: London, UK, 2009. Available online: http://www.neweconomics.org/publications/entry/a-bit-rich (accessed on 27 February 2014).

52. Victor, P.A. Questioning economic growth. Nature 2010, 468, 370-371.

53. Coote, A.; Franklin, J.; Simms, A. 21 Hours. Why a Shorter Working Week can Help Us All to Flourish in the 21st Century; New Economics Foundation: London, UK, 2010. Available online: http://www.neweconomics.org/publications/entry/21-hours (accessed on 27 February 2014).

54. MacGregor, S. Citizenship and Care. In Understanding the Environment and Social Policy; Fitzpatrick, T., Ed.; Policy Press and Social Policy Association: Bristol, UK, 2011; pp. 271-289.

55. Norton, C. Social work and the environment: An ecosocial approach. Int. J. Soc. Welf. 2012, 21, 299-308.

56. Haubenhofer, D.K.; Elings, M.; Hassink, J.; Hine, R.E. The Development of Green Care in Western European Countries. Explore J. Sci. Heal. 2010, 6, 106-111.

57. Hamilton, C. Consumerism, self-creation and prospects for a new ecological consciousness. J. Clean. Prod. 2010, 18, 571-575.

58. Kilpinen, E. Human Beings as Creatures of Habit. In The Habits of Consumption; Warde, A., Southarton, D., Eds.; Helsinki Collegium for Advanced Studies: Helsinki, Finland, 2012; pp. 45-69. Available online: https://helda.helsinki.fi/handle/10138/34221 (accessed on 28 January 2014).

59. Of European origin, the ideology of man's domination over nature has permeated the deepest layers of consciousness not only in western civilization but in nearly every culture on the planet.

60. Meadows, D. Indicators and Information Systems for Sustainable Development. A Report to the Balaton Group; The Sustainability Institute: Hartland, VT, USA, 1998. Available online: http://www.iisd.org/pdf/s_ind_2.pdf (accessed on 3 May 2013).

61. Sen, A.K. The Idea of Justice; The Belknap Press of Harvard University Press: Cambridge, MA, USA, 2009; p. 467.

62. Allardt, E. Dimensions of welfare in a Comparative Scandinavian Study. Acta. Sociol. 1976, 19, 227-239.

63. It is often thought that Maslow's theory of needs is strictly hierarchical and quite rigid. Yet, Maslow saw human needs as relatively fluid, with many needs being present simultaneously [26].

(C) 2014 by the authors; licensee MDPI, Basel, Switzerland. This article is an open access article distributed under the terms and conditions of the Creative Commons Attribution license (http://creativecommons.org/licenses/by/3.0/). 